\title{
UPAYA MENINGKATKAN HASIL BELAJAR PESERTA DIDIK PADA MATA PELAJARAN MATEMATIKA MENGGUNAKAN MODEL MAKE A MATCH DENGAN BERBANTUAN MEDIA FLIP CHART KELAS IV SDN-2 KASONGAN BARU TAHUN PELAJARAN 2016/2017
}

\section{Oleh :Azizah Febriani *Dedy Setyawan, M.Pd}

\begin{abstract}
Abstrak
Penelitian ini bertujuan untuk mengetahui: (1) Aktivitas Belajar Peserta Didik, (2) Mengetahui Peningkatan Hasil Belajar Matematika Setelah Menggunakan Model Make a Matchberbantuan media Flip ChartPada Materi PenjumlahanPecahan dikelas IV SDN-2 Kasongan Baru.Penelitian ini merupakan penelitian tindakan kelas (PTK). Subjek penelitian ini adalah peserta didik kelas IV SDN-2 Kasongan Baru Tahun Pelajaran 2016/2017 yang terdiri dari 12 peserta didik. Analisis data yang digunakan dalam penelitian ini adalah data kuantitatif dan data kualitatif.Berdasarkan penelitian diperoleh: (1) Aktivitas belajar peserta didik kelas IV SDN-2 Kasongan Baru setelah menggunakan modelMake a Matchberbantuan media Flip Chartpada siklus I skor rata-rata 3,45menjadibaik. Dari observasi yang telah dilakukan dapat disimpulkan bahwa aktivitas belajar peserta didik masuk dalam kategori baik. (2) Ada peningkatan hasil belajar peserta didik kelas IV SDN-2 Kasongan Baru dengan menggunakan modelMake a Matchberbantuan media Flip Chartmengalami peningkatan dari data awal rata-rata 44 dan ketuntasan klasikal 33\%. Nilai rata-rata pada siklus I 76dan ketuntasan secara klasikal $100 \%$.
\end{abstract}

Kata Kunci: Hasil Belajar Matematika, dan Model Make a Match berbantuan media Flip Chart

\section{PENDAHULUAN}

Dalam arti sederhana pendidikan sering diartikan sebagai usaha manusia untuk membina kepribadian nya sesuai dengan nilai-nilai didalam masyarakat dan kebudayaan. Dalam perkembangannya, istilah pendidikan atau paedagogie berarti bimbingan ataup ertolongan yang diberikan dengan sengaja oleh orang dewasa agar ia menjadi dewasa. Menurut UU No. 20 Tahun 2003, Pendidikan adalah usaha sadar dan terencana untuk mewujudkan suasana belajar dan proses pembelajaran agar peserta didik secara aktif mengembangkan potensi dirinya untuk memiliki kekuatan spriritual keagamaan, pengendalian diri, ke pribadian, kecerdasan, akhlak mulia, serta keterampilan yang diperlukan dirinya, masyarakat, bangsa, dan Negara. Hasbullah. (2011). Dasar-dasar Ilmu Pendidikan. Jakarta : Rajawali Pers.

Sekolah merupakan pusat semua sumber belajar yang berfungsi guna mempersiapkan peserta didik sehingga 
dapat terjun dalam kehidupan bermasyarakat dalam hal ini guru hanya merupakan fasilitator bagi peserta didik. Disekolah inilah pendidikan diberikan langsung oleh seorang guru terhadap peserta didiknya. Didalam perkembangan pembelajaran yang dilaksanakan saat ini banyak ditemukan masalahmasalah tentang kurangnya minat peserta didik dalam mengikuti proses pembelajaran sehingga peserta didik kurang memperhatikan penjelasandari guru, tujuan pembelajaran yang seharusnya tercapai dan dikuasai peserta didik banyak yang tidak sesuai dengan harapan yang diinginkan pada indikator pembelajaran. Pada semua mata pelajaran peserta didik selalu dituntut untuk menguasai materi baik teori maupun penerapannya dalam kehidupan sehari-hari selalu diawali dengan keterampilan matematika.

Maka dari itu diperlukan model, metode dan media pembelajaran yang inovatif. Berdasarkan uraian diatas penulis tertarik untuk melakukan penelitian yang berkaitan dengan penggunaan model pembelajaran utamanya pada pembelajaran Matematika di SDN-2 Kasongan Baru Kabupaten Katingan. Berdasarkan hasil observasi yang dilakukan peneliti pada tanggal 28 Februari 2017, kelas IV di SDN-2 Kasongan Baru maka peneliti menemukan masalah atau kendala yaitu kurangnya antusias peserta didik dalam mengikuti proses pembelajaran sehingga ada peserta didik kurang memperhatikan penjelasan dari guru, masih ada nya peserta didik kelas IV SDN-2 Kasongan Baru yang belum terampil matematika, hal ini disebab kan oleh kurangnya variasi model pembelajaran dalam pembelajaran matematika. Salah satu penyebab terjadinya hal tersebut adalah karena guru kurang tepat dalam memilih media pembelajran yang sesuai dengan materi yang disampaikan. Hasil belajar peserta didik dalam mata pelajaran matematika masih rendah yaitud engan rata-rata 55. Sedangkan kriteria ketuntasan minimal (KKM) yang ditetap kan oleh SDN-2 Kasongan Baru yaitu 60. Aada 9 peserta didik (75\%) dari jumlah peserta didik di kelas IV mendapat nilai $<60$ dan sisanya 3 peserta didik (25\%) mendapat nilai $\geq 60$. Hal tersebut berdasarkan informasi yang diperoleh peneliti dari wali kelas IV SDN-2 Kasongan Baru.

Peneliti menggunakan model Make a Match dalam pembelajaran matematika SD guna membuat peserta didik lebih mudah memahami materi pembelajaran dan bisa membuat peserta didik menjadi aktif berpartisipasi dalam pembelajaran kooperatif. Model ini dikembangkan oleh Lorna Curran (2014:223). Salah satu keunggulan teknik ini adalah peserta didik mencari pasangan sambil belajar mengenai suatu konsep atau topik, dalam suasana yang menyenangkan. Oleh sebab itu peneliti ingin mencoba menggunakan model Make a Match untuk meningkatkan 
kemampuan peserta didik pada mata pelajaran matematika agar mencapai standar kriteria ketuntasan minimal (KKM) yang diteetap kan oleh SDN-2 Kasongan Baru. Berdasarkan uraian diatas maka peneliti tertarik untuk melakukan penelitian tindakan kelas yang berjudul "Upaya Meningkatkan Hasil Belajar Peserta Didik Pada Mata Pelajaran Matematika Menggunakan Model Make a Match Dengan Berbantuan Media Flip Chart Kelas IV SDN-2 Kasongan Baru Tahun Pelajaran 2016/2017.”

\section{METODOLOGI}

Penelitian ini dilaksanakan di Sekolah Dasar Negeri 2 Kasongan Baru untuk mata pelajaran Matematika Kelas IV. Lokasi penelitian terletak di Jalan Pusara Cinta No. 29 Kecamatan Katingan Hilir. Metode yang digunakan dalam penelitian ini adalah Penelitian Tindakan Kelas (PTK). Subjek penelitian seluruh peserta didik kelas IV SDN-2 Kasongan Baru Tahun Pelajaran 2016/2017 yang berjumlah 12 orang 4 orang laki-laki dan 8 perempuan. Teknik pengumpulan data yang digunakan adalah Observasi dan Tes. Teknik Analisis Data yang digunakan Kualitatif dan Kuantitatif.

\section{HASIL DAN PEMBAHASAN}

Berdasarkan hasil penelitian deskripsi data yang disajikan terdiri dari dua jenis yaitu, data pra tindakan, data siklus I. Data pra tindakan adalah tes awal sebelum diterapkannya tindakan kelas menggunakan Model Make a Match pada proses kegiatan pembelajaran yang dilakukan oleh peneliti, sedangkan siklus I adalah hasil dari kegiatan pembelajaran tindakan kelas melalui strategi Index Berdasarkan data pra tindakan adalah terdiri dari tes awal (pre test) pada mata pelajaran Matematika, pada hari Kamis tanggal 20 April 2017 pada pukul 07.00-08.45 wib, tes ditentukan dengan memberikan soal isian dengan jumlah 10 soal, yang di mana proses pembelajaran dilakukan secara Konvensional dan belum menggunakan model Make a Match ternyata hasilnya kurang memuaskan.

Hasil belajar yang diperoleh peserta didik pada tes awal (pre test) pra siklus pada kelas IV SDN-2 Kasongan Baru memperoleh nilai rata-rata 44 dan dengan ketuntasan klasikal 33\% dari 12 peserta didik yang memperoleh nilai 60 keatas sebanyak 4 peserta didik (33\%), sedangkan yang memperoleh nilai dibawah 60 sebanyak 8 peserta didik (67\%). Jadi, dapat diketahui bahwa ketuntasan hasil belajar peserta didik belum memenuhi ketuntasan hasil belajar secara klasikal yaitu sebesar $85 \%$.

1) Dari 12 orang peserta didik ada 4 peserta didik yang memperoleh skor 60-100.

2) Dari 12 orang peserta didik ada 8 peserta didik yang memperoleh skor 20-50. 
Perolehan skor rata-rata kelas II SDN-2 Kasongan Baru dari 12 peserta didik adalah 44 konsep yang diterima peserta didik tentang materi Penjumlahanpecahanbelum tercapai, artinya belum mencapai KKM meskipun materi yang telah diajarkan, oleh karena itu dilakukan upaya perbaikan dengan mengidentifikasi kekurangan dari pembelajaran Matematika yang telah dilaksanakan di kelas IV SDN-2 Kasongan Baru.

Data hasil belajar yang diperoleh dari post test pada siklus I yang diberikan setelah selesai proses kegiatan dalam mata pelajaran Matematika materi penjumlahan pecahan dengan menggunakan model Make a Match. Soal yang diberikan pada post test yaitu berjumlah 10 soal isian.

Berdasarkan hasil belajar siklus I terlihat hasil belajar peserta didik di kelas IV SDN-2 Kasongan Baru memperoleh nilai rata-rata 76 dengan ketuntasan klasikal $85 \%$ termasuk kriteria tercapai. Danmencapai ketuntasan belajar yang ditetapkan untuk mata pelajaran IPA yaitu 60 .

Dari hasil post test menunjukkan tingkat kemampuan peserta didik pada saat penelitian tindakan kelas pada siklus I secara rinci diuraikan sebagai berikut:

1) Dari 12 orang peserta didik hanya ada 4 orang peserta didik yang memperoleh skor 60
2) Dari 12 orang peserta didik hanya ada 8 orang peserta didik yang memperoleh skor 20-50

Jadi, dapat diketahui bahwa ketuntasan hasil belajar peserta didikmemenuhi ketuntasan hasil belajar secara klasikal.

Berdasarkan hasil tes siklus I terlihat dari nilai hasil belajar IPA peserta didik kelas IV SDN-2 Kasongan Baru. Dengan rata-rata 100 tingkat keberhasilan pembelajaran sudah memenuhi syarat ketutantasan klasikal yaitu $100 \%$.

Pada tahap awal disaat observasi sebelum menerapkan siklus I dengan menggunakan model Make a Match hasil belajar peserta didik masih rendah. Namun ketika diterapkan siklus I aktivitas belajar peserta didik dari 12 peserta didik rata-rata hasil pengamatan aktivitas yaitu 3,45. Hasil belajar peserta didik yang perhitungannya didapat dari hasil siklus I dengan nilai rata-rata 76 dengan ketuntasan klasikal 100\%dengan demikian pada saat siklus I memenuhi ketercapaian ketuntasan terhadap hasil belajar peserta didik secara klasikal sehingga peneliti mengganggap berhasil.

Hasil observasipada siklus I mendiskripsikan adanya peningkatan yang baik dalam proses kegiatan pembelajaran Matematika dengan materi penjumlahan pecahan dengan menggunakan model Make a Match, dari hasilobservasi diatas ada 
peningkatan hasil observasi siklus I dalam peningkatan aktivitas guru dan peserta didik. Dimana peningkatan aktivitas guru dan peserta didik, berpengaruh terhadap hasil belajar peserta didik. Pada siklus I hasil belajar peserta didik mengalami peningkatan dengan 12 orang peserta didik memperoleh nilai tuntas dalam mengikuti pembelajaran dari jumlah sebanyak 12 orang peserta didik. Jadi, dari jumlah 12 orang peserta didik, 12 orang peserta didik mendapat nilai tuntas yang memenuhi Kreteria Ketuntasan minimal (KKM), dengan demikian penelitian ini dikatakan berhasil dan tidak perlu dilanjutkan ke siklus berikutnya.

Dari pelaksanaan tindakan siklus I dapat disimpulkan bahwa dapat dikatakan baik dan peneliti telah bisa memperbaiki hambatan dan kekurangan/kelemahan pada pratindakan. Adapun keterangan sebagai berikut:

1. Aktivitas guru dan peserta didik dalam proses pembelajaran sudah baik dan mengalami peningkatan,hampir semua peserta didik sudah terbiasa dengan kondisi belajar dengan menggunakan model Make a Match.

2. Peserta didik terlihat mulai memiliki keberanian dan aktif dalam pembelajaran

3. Gurujelas dalam menyampaikan tujuan pembelajaran
4. Hasil belajar peserta didik meningkat dari peningkatan yang terjadi dari jumlah 12 peserta didik kelas IV SDN-2 Kasongan Baru.

Dapat dibuktikan dari hasil tes siklus I sebesar (100\%) atau 12 peserta didik yang mencapai KKM.

\section{SIMPULAN}

1. Aktivitas belajar peserta didik kelas IV SDN-2 Kasongan Baru setelah menggunakan Model Make aMatch pada siklus I skor rata-rata 3,45menjadi baik. Dari observasi yang telah dilakukan dapat disimpulkan bahwa aktivitas belajar peserta didik masuk dalam kategori baik.

2. Ada peningkatan hasil belajar peserta didik kelas IV SDN-2 Kasongan Baru dengan menggunakan model Make a Match mengalami peningkatan dari data awal rata-rata 44 dan ketuntasan klasikal 33\%. Nilai rata-rata pada siklus I 76 dengan ketuntasan klasikal 100\%.

\section{DAFTAR PUSTAKA}

\author{
Hasbullah.(2011). Dasar-dasar Ilmu \\ Pendidikan .Jakarta : Rajawali \\ Pers.
}


Tunas Jurnas Pendidikan Guru Sekolah Dasar, Juni 2018 Volume 3 Nomor 2, (1-8) ISSN 2477-6076 